\title{
Sociologia da Educação de Max Weber: o Clinamen' na prática pedagógica
}

Alonso Bezerra Carvalho ${ }^{2}$

\section{Resumo}

Este artigo consiste, fundamentalmente, em uma análise do pensamento de Max Weber, de maneira a buscar uma possível contribuição ao campo da educação na atualidade. Ao expor sua compreensão sobre o processo de racionalização, tendo na burocracia uma de suas manifestações mais contundentes, Weber compreende as ações humanas como constituídas de uma tensão permanente. Não haveria no mundo um sentido, com validade universal, que orientasse a existência. Neste aspecto, a educação precisa adquirir outro significado, isto é, uma educação que faça o clinamen surgir e ressurgir, introduzindo no mecanismo determinista o espaço de libertação, que consiste em romper o determinismo inerente a qualquer situação objetiva e, de forma desviante, abrir espaço para o exercício da autonomia. Se ao professor cumpre fornecer alguma esperança para a vida de seus alunos, esta deve ser estabelecida a partir do reconhecimento do caráter agonístico da existência. Agir assim é garantir a integridade e a liberdade intelectual.

Palavras-chave: desencantamento do mundo; burocracia; processo de racionalização; sociologia da educação; prática pedagógica.

I O filósofo José Américo Motta Pessanha ao analisar o pensamento de Epicuro, reporta-se à ideia do clinamen. Segundo ele, "[...] o clinamen [desvio] é condição indispensável para que o mundo, cuja existência é provada por nossos sentidos, fosse gerado. O que vale dizer: a passagem do possível ao real exige um desvio - mínimo - das leis mecânicas; deixadas só em si mesmas, elas estabelecem um cenário racional onde o mundo é apenas possibilidade abstrata [...] O clinamen [...] também explica a possibilidade de o homem reorientar sua vida interior, desviando-se de sensações dolorosas para ir ao encontro do prazer. A liberdade - para ser feliz mesmo na adversidade - subtende o desvio, a recusa da fatalidade" (PESSANHA, 1997, p. 71, grifo do autor).

2 Professor do Departamento de Didática e do Programa de Pós-Graduação em Educação da Faculdade de Filosofia e Ciências, da UNESP, Campus de Marília. Líder do Grupo de Estudo e Pesquisa em Educação, Ética e Sociedade (GEPEES), cadastrado no CNPq. E-mail: alonso.carvalho@unesp.br. atribua a autoria da obra, forneça um link para a licença, e indicar se foram feitas alterações. 


\section{Introdução}

É possível formular uma concepção pedagógica weberiana? É o que pretendemos responder. Se conhecemos os trabalhos e as ideias de Weber como pertencentes ao campo da sociologia, isso não impede de colocá-los em contato com outras áreas do conhecimento. A sociologia de Weber traz questôes importantíssimas do ponto de vista filosófico, antropológico e para a psicologia. Neste artigo, o objetivo é relacionar estas questóes à educação. É verdade que não é nossa pretensão tratá-las como objeto específico do campo pedagógico, tornando Weber mais um pensador da educação. Os temas weberianos que serão apresentados nos fornecem elementos para rediscutirmos o significado que a educação teve e ainda tem em um mundo que foi desencantado.

De início, tentemos imaginar como, geralmente, é o cotidiano de uma sala de aula: os alunos sentam-se enfileirados, vestidos uniformemente, obrigados a se comportarem também uniformemente - com uma postura ereta, silenciosos e atentos aos ensinamentos -, proporcionando condiçóes para absorverem os conhecimentos de outra pessoa, o professor, que se julga detentor do conhecimento, pelo menos da área previamente proposta pela instituição. Esta imagem, todavia, representa um olhar desatento sobre uma sala de aula. Com um olhar mais apurado, percebemos que cada aluno possui uma história de vida, experiências peculiares, pensamentos únicos e, principalmente, comportamentos e sentimentos diferenciados. Tomamos, neste sentido, que a uniformidade não se torna tão clara quanto parecia anteriormente. Tais alunos, geralmente tratados como iguais, são colocados em uma condiçáo de aprendizagem dos mesmos conteúdos, na mesma velocidade e da mesma forma. Não se respeitam seus conhecimentos prévios, suas diferenças em termos de capacidade, muito menos suas opiniốes sobre o que se está aprendendo. O aluno tem apenas o dever de aprender em um tempo determinado, de uma forma preestabelecida e configurada de acordo com o que se cobra na sociedade. Vemos, neste âmbito, um processo de homogeneização, vítima de uma racionalização, produzida a partir de modelos, os quais se tornam almejados, porém raramente alcançados.

Talvez o vínculo educacional mais forte existente na instituição seja aquele formado entre o professor e o aluno. Tal vínculo é alimentado, 
por parte do professor, pelas suas expectativas em passar o conhecimento, adquirido através de estudos ao longo da vida; e, para os alunos, este vínculo é mantido, após uma provável identificação com o professor, pela expectativa de obter uma profissão. Quanto às pretensóes do professor, de conseguir fazer com que seus alunos adquiram o conhecimento necessário para poder almejar uma profissão de sucesso, é preciso atentar para que caminho escolher.

Podemos partir da ideia de que o objetivo principal da educação é proporcionar aos alunos um conteúdo que incentive a reflexão. Porém, para que isso aconteça, não basta somente conteúdo, é necessário também pensar a maneira como este é passado. Para isso, é preciso que o professor adote uma ética não partidária na sala de aula, ou seja, é necessário que o professor, ao apresentar um conteúdo, não exponha a sua opiniáo sobre este e, se o fizer, tenha a honestidade de dizer que o está fazendo. É preciso que ele incentive o aluno a refletir sobre o que foi apresentado e, então, adotar uma opiniáo condizente com a sua compreensão. Assim, é de extrema importância que o professor mantenha uma posição "neutra" para que, não só na sala de aula mas também fora dela, o aluno possa refletir e questionar sobre o que observa, experimenta e decide.

A importância desta atitude do professor justifica-se na medida em que o aluno se encontra num processo de formação identificatória, até mesmo em relaçáo ao próprio professor. Esse processo de identificação, antes ocorrido apenas em âmbito familiar, se estende para a vida social e, principalmente, para a instituição educacional. Partindo-se desse princípio, o professor adquire um papel de extrema importância para a formação do aluno, priorizando sua independência de reflexão sobre o mundo que o cerca, dando-lhe a capacidade de questionar e afirmar, oferecendo condiçóes para construir crenças e proposiçóes condizentes com suas características.

Porém, muitos professores não adotam esta maneira de ensinar e, sim, uma postura muitas vezes ditatorial, passando como um rolo compressor pelas diferenças dos alunos, impondo seu ponto de vista sobre assuntos que deveriam ser discutidos em sala de aula, mas que, na verdade, são 
"despejados" nos alunos - considerados como "folhas em branco" -, em detrimento de suas peculiaridades e opinióes.

A educação, constituída com esse caráter institucional, racional e burocrático, parece impedir uma liberdade maior de construção do conhecimento por parte dos alunos, presos que estấo a uma espécie de treinamento. Um espírito carismático não sobressai nessa relação, mas apenas o burocrático-disciplinador.

Há de se supor, a partir dessas constataçóes inspiradas no pensamento de Weber, que fica cada vez mais intenso o processo de massificaçáo, com a construção contínua de modelos, que tem início já na escola e que acompanhará o indivíduo em todo o decorrer de sua vida. $\mathrm{O}$ mundo racionalizado, usando dos meios burocráticos, transforma a escola em uma forma de almejar a posição de algum modelo, construído por esta mesma sociedade, de acordo com as suas necessidades, obrigando o ser humano, enquanto inserido em todo esse processo, a limitar suas opçôes. Parece configurar-se, aqui, o sofrimento da humanidade, tornando então notório o grande envolvimento da sociologia weberiana com os "problemas da atualidade", como chama a atenção Foucault ${ }^{3}$. Contudo, a possibilidade de mudança de tal quadro não pode ser ignorada; assim, para equilibrá-lo, é preciso despertar o carisma.

A indagação que percorre as investigações weberianas refere-se ao homem especificamente moderno, que pode ser visto na perspectiva de sua personalidade, da cultura ou da sociedade. Weber estuda o presente, a atualidade, o agora, procurando o que lhe é específico; porém, com uma diferença: o mundo moderno perdeu o seu signum, ou seja, não há um progresso em direção ao melhor. Ele não faz um prognóstico, mas, sim, um diagnóstico da modernidade, olhando o mundo empírico na dureza dos fatos desagradáveis que o constituem. Não o higieniza, não o perfuma.

3 Segundo Foucault (1984), Weber é um dos pensadores que procurou compreender o mundo ocidental moderno dentro dos limites que a própria modernidade colocou a si mesma. A "ontologia do presente" weberiana trata das exigências que o cotidiano faz aos homens, exigências estas que, muitas vezes, o homem não está em condições de atender. Essa posição filosófica, preocupada com uma "ontologia de nós mesmos", fundou uma forma de reflexão que vai "de Hegel à Escola de Frankfurt, passando por Nietzsche e Max Weber" (FOUCAULT, 1984, p. II2). 
Até pensa que a razão trouxe coisas boas, mas indica também que, junto com ela, vieram a perda de sentido e uma irracionalidade destrutiva - uma razão antinômica. O diagnóstico weberiano está centrado em elementos indicativos de que o homem moderno perdeu o sentido. Não há mais forças misteriosas, transcendentes e determinantes que orientem a ação humana. $\mathrm{O}$ mundo reificado produziu pessoas que se tornaram especialistas sem espirito e hedonistas sem coraçâo.

Se pararmos por aqui, a conclusão mais plausível é a de que Weber é um pessimista. Estaríamos submetidos a uma "carapaça dura como aço" (stahlhartes Gehäuse) que, como na caverna platônica, nos prende a grilhôes difíceis de serem quebrados. Mas podemos afirmar, com certo grau de segurança, que essa leitura encontra-se, sim, nos textos de Weber, mas restringir-se a ela é perder a riqueza de seu pensamento. É possível deduzir de sua diagnose uma prognose, ou seja, o mesmo mundo que domina gera as condiçóes para o surgimento das figuras chamadas por Jessé Souza (1997, p. 112, grifo do autor) de "especialista com espírito e do homem do prazer com coração".

\section{A sociologia weberiana e a modernidade: questões para se pensar a educação}

A problematização trazida por Weber sugere que sua posição estaria além de uma mera crítica resignada, mas seria uma espécie de "terapia" contra os efeitos alienantes e patológicos típicos do cotidiano moderno. Haveria, portanto, em Weber, dois caminhos: o do pessimismo cultural, que é o momento de denúncia das condiçôes modernas, e aquele que adota as perspectivas terapêuticas, o momento de esperança em uma sociedade diferente ${ }^{4}$. Weber deposita sua confiança na liberação de forças capazes de possibilitar uma atitude de resistência contra as instituiçôes burocráticas e o "casulo da servidão".

A ideia de vocação moderna na Reforma, inicialmente, ganha os contornos de uma superação da religiosidade pela ascese monástica, na

4 Henrich, Offe e Schluchter (1990, p. 230-233) mencionam que Weber, além de historiador e diagnosticador das condições modernas, trata-se também de um terapeuta - analisa como devemos reagir a essas condições. 
medida em que afirma que a satisfação dos deveres intramundanos é o único caminho para agradar a Deus. Esse ethos estende-se às coisas do mundo, perde o caráter divino. A conexão entre a doutrina da predestinação e a "certeza da salvação" produz o estímulo para uma condução da vida ascética, antitradicionalista, intramundana e metódica. Esse comportamento representa, de certa forma, o surgimento da liberdade moderna.

Nesse sentido, Weber é simpático a esse homem puritano, pois o seu ascetismo capacita-o para uma vida clara, desperta e consciente. Esse seria o aspecto positivo do puritanismo. Porém, se os ideais éticos do ascetismo puritano favoreceram o surgimento do espírito capitalista, os resultados desse processo fugiram do controle. As consequências advindas são paradoxais. Fazendo referência à América, afirma:

No setor de seu mais alto desenvolvimento, nos Estados Unidos, a procura da riqueza, despida de sua roupagem ético-religiosa, tende cada vez mais a associar-se com paixões puramente mundanas, que frequentemente lhe dão o caráter de esporte. (WEBER, 1967, p. 131).

Uma das consequências, não previstas, da conduta do homem puritano foi o "desencantamento do mundo", que retirou as condiçóes de validade dessa conduta do mundo mágico-religioso. A concepção de mundo que se baseava numa ética material, - substantiva e com valor universal -, funcionando como substrato das relaçóes entre os homens e regulando, com ambiçóes totalitárias, o espaço público pertence definitivamente ao passado. Weber estava perfeitamente consciente de que vivia na época do "individualismo ético". O mundo objetivo não tem nenhum significado em si, e a tarefa de conferir significado a este mundo é uma tarefa individual e solitária. Cada qual está só com o seu Deus ou demônio que rege as suas escolhas significativas. Não há mais nenhum Deus, nenhum sacramento e nenhum sacerdote que explique e dê sentido à existência humana em seu conjunto.

Ademais, temos um processo de especialização, como consequência da progressiva divisão social do trabalho. Nesse ambiente, a personalidade do homem moderno estaria como que subsumida aos grilhóes de uma prisão.

$\mathrm{Na}$ modernidade diagnosticada por Weber, o que importa é a superação e a renúncia das paixões, que obscurecem e desviam. Renúncia adquire 
aqui, portanto, o sentido de uma subordinação do sujeito em relação às condições não escolhidas do mundo impessoal. Segundo ele, a presença de Goethe nesse diagnóstico é cristalina, pois ação e renúncia condicionam-se reciprocamente na medida em que o trabalho, no mundo moderno, exige, necessariamente, uma limitação a uma pequena esfera da atividade produtiva em cada área de atividade; e isso pressupóe, ao mesmo tempo, concentração de esforços e aumento do desempenho.

A limitação do trabalho especializado, com a renúncia à Faustiana universalidade do homem por ela subentendida, é uma condição para qualquer trabalho válido no mundo contemporâneo; daí a "ação" e "renúncia" hoje inevitavelmente se condicionarem uma à outra. Esse traço fundamentalmente ascético do estilo de vida [...] foi o que Goethe quis nos ensinar no auge de sua sabedoria [...] Para ele, essa consciência implicava a despedida de uma era de plenitude e beleza humana que, no decorrer de nosso desenvolvimento cultural tem tão poucas chances de se repetir como a época de florescimento da cultura ateniense da Antiguidade. (WEBER, 1967, p. 130).

Como vemos, da análise de Weber é possível retirar afirmaçóes que expressam ainda uma expectativa, que - embora náo seja rósea - é ainda um lampejo de esperança. Se nossa época está desencantada, pelo menos podemos intuir, olhando o passado, "o renascimento de velhos pensamentos e ideias”, como Nietzsche fez ao olhar para os gregos. Nem tudo está perdido, diria Weber. Em alguns de seus textos, embora trate das antinomias da vida social moderna, mesmo que assistematicamente, encontramos alguns apontamentos que, se forem considerados na ação educativa, podem ainda render alguns bons frutos.

A tipologia pedagógica, que emana da análise sociológica weberiana sobre o mundo moderno, exige dos homens uma ética aristocrática e heroica. Primeiramente, porque é privilégio de poucos, visto que a regra é a acomodação à ausência de sentido e de liberdade; segundo, porque está na mais radical oposição em relação às leis das estruturas objetivas do mundo racionalizado, no sentido que luta ainda para manter um espaço de valores éticos em uma época em que esses valores parecem terem sido definitivamente expulsos do espaço público.

Vemos, aqui, o que Weber veio a chamar de "paradoxo das consequências”. Isso significa que se produziu uma tragédia que não foi originalmente 
intencionada. Os puritanos teriam criado, sem querer, a "carapaça dura como aço" das instituiçóes capitalistas ao tentarem realizar os mandamentos de Deus na Terra. A "nova escravidáo" assume a forma de uma oposição entre as lógicas individual e institucional. A lógica institucional materializa-se na disciplinarização antilibertária dos indivíduos, de acordo com seus próprios fins institucionais que são, agora, independentes dos fins individuais. A liberdade, no sentido weberiano, é expulsa do espaço público. Há uma racionalizaçáo técnica da conduta da vida humana, que obedece às regras passíveis de serem generalizadas segundo padróes de eficiência. Essas "patologias da modernidade", que exigem uma terapia, podem ser superadas com a ação pedagógica.

É isso que podemos depreender das ideias weberianas. A conduta de professores e alunos em uma instituição, do ponto de vista das relaçóes humanas e profissionais, pode preparar o terreno para "[suportarmos] o destino de nossa época”. Portanto, vemos em Weber, não apenas um autor que constata a tragédia do mundo moderno, no qual convivem os paradoxos de uma existência fundada na inevitabilidade da renúncia. É possível uma educação que equilibre a tensáo entre um mundo que se tornou burocrático e despersonalizado burocraticamente e a possibilidade de atitudes carismáticas.

O caráter revolucionário do carisma é compreendido por Weber como o rompimento com as rotinas cotidianas e com todas as normas racionais. A manifestaçáo extática da ação carismática, que experimenta a sensação produzida por aqueles que praticam a música, a dança, o sexo etc., representa um estado além da razão. Aplica-se

[...] tanto à adoração de Romeu por Julieta quando à raiva de Otelo no assassinato de Desdêmona. Tanto Romeu quanto Otelo são retirados para fora de si por emoções poderosas de arrebatamento e raiva que provocam expressões apaixonadas e frenéticas [...] Como o deus Dioniso, o carisma "representa a própria força viva encarnada, o ímpeto da seiva na árvore e o do sangue nas veias [...] Revoluciona os homens a partir de dentro", liberando os elementos emocionais e instintivos previamente reprimidos pela existência cotidiana. (DOW JR., 1978, p. 84).

Todavia, Weber não defende uma conduta que seja integralmente extática, como as Mênades estraçalhando Penteu em As Bacantes, de Eurípedes. 
Ao invés de uma selvageria caótica, uma ação controlada e apaixonada, como encontramos no texto A política como vocação. Permanecer para além do alcance da dominação burocrática significa ampliar a conduta individual diferenciada, sem, no entanto, abrir mão da responsabilidade. É possível aventurar-se sem desconhecer as regras. Se a algum tipo de homem é dada a chance de colocar a mão na roda da história, este homem deve ter as qualidades carismáticas e a disciplina - instrumento da racionalização.

Para Weber, então, nem a completa repressão nem a completa liberação representa um comportamento "maduro" ou "genuinamente humano" [...] O homem "genuíno" representa uma síntese do carisma e do ascetismo [...], sua alma está "livre"” para se expressar apaixonadamente em defesa de uma ética da responsabilidade [...]. [Weber, portanto,] não quer sancionar totalmente o irracional como uma solução. (DOW JR., 1978, p. 87).

Weber foi professor, cientista e tentou ser político. Tinha alguma esperança na "superação" de uma existência que prendia o homem a uma couraça, impossibilitando, assim, a manifestação de sua liberdade. Almejou construir um pensamento que compreendesse as condiçóes modernas naquilo que elas têm de específico em comparação a outras épocas e concluiu que nós vivemos em um mundo que perdeu os seus valores transcendentais. Não haveria, na modernidade, um sistema de valores universais que justificasse as açóes dos homens. Estaríamos diante apenas dos nossos próprios valores, que cada um cria para orientar a sua conduta.

Como já dissemos, Weber desconfia das profecias científicas ou filosóficas que postulam um melhoramento cada vez maior da humanidade, seja em direção a uma sociedade harmoniosa e solidária, como queria Durkheim, justa, fraterna e socialista, como pensa Marx, ou perfeita e cosmopolita, como acredita Kant. Se encontramos neles a tranquila crença em um progresso inevitável, em uma autonomização, engrandecimento e sofisticação contínuos do espírito individual, para Weber, o mundo ocidental moderno - em especial o mundo europeu-americano, com o seu processo racional-burocrático, resultado do desencantamento do mundo - deixou aos homens, como consequência não desejada do protestantismo ascético, uma “irracionalidade ética”. O politeísmo de valores é o sinal de nossos tempos. Diante dessa situação não há mais uma teoria ética, metafisicamente constituída, que sustente qualquer escolha feita pelos homens. E não há ciência e nenhuma ação educativa que possa ajudar a resolver esse problema. 
O processo de racionalização do Ocidente solicita aos homens agirem com virilidade, resistindo e enfrentando o quanto puderem "as exigências do cotidiano". Os tempos modernos são aqueles em que os grilhóes inumanos e frios estáo difundidos por toda parte. A vida transformou-se em um contínuo uso individual de instrumentos, dos quais o Outro vem a ser o mais útil. E, para governar homens assim privados e "coisificados", nada melhor do que a burocracia, em todas as suas faces, o que fez Weber chamar a atenção de seus contemporâneos para as graves consequências que a desapariçáo da vida pública e dos grandes valores humanos traria para o Ocidente.

O carisma é, em Weber, o contraponto para pensarmos em uma "saída" de uma era submetida à "carapaça dura como aço”. Com essa noção, ele alimenta a esperança de vivermos livres das garras de um sistema que nos aprisiona. Se a educação quiser garantir uma existência saudável, devemos nos esforçar para equilibrar o jogo em que a burocracia está vencendo. Ao buscar uma integração entre o carisma e o ascetismo, Weber acredita que a paixão, a serviço de uma ética da responsabilidade, possa ainda salvar o homem da imaturidade e da desumanidade, tanto das rotinas cotidianas quanto da manifestação extática irresponsável (DOW JR., 1978, p. 91). O compromisso ético do homem e, por extensão, da educação é fazer com que essa tensão se equilibre; e Weber teve essa esperança tanto como homem quanto como acadêmico.

A educação carismática e a educação especializada, burocrática, nos ajudam a compreender a "saída" que Weber procura para a cultura moderna. Se ele percebia a pedagogia racional-burocrática como predominante na vida ocidental moderna, por outro lado, apontava que é possível equilibrar esse domínio com o despertar do carisma; porém, contrabalançar essas duas forças não significa estar diante de um progresso da humanidade em direção a uma sociedade solidária, harmoniosa e perfeita. Na verdade, estamos apenas reconhecendo que a vida é uma permanente luta de perspectivas, tanto hoje como antigamente. "Vivemos como os antigos, quando o seu mundo ainda não havia sido desencantado de seus deuses e demônios" (WEBER, 1982, p. 175). Para suportarmos, em nossos tempos, as exigências de cada dia, devemos reconhecer, em primeiro lugar, este destino.

Falar do "destino de nosso tempo" e de educação exige de nós a disposição de provocar e fustigar a sua aparente tranquilidade. E aqui Nietzsche, 
com a noção de apolíneo e dionisíaco, pode nos ajudar a entender esse diagnóstico weberiano. Aquele filósofo repóe a dimensão dionisíaca no palco da existência humana. Isso quer dizer que não precisamos aprender a separar o "fazer não" do "dizer-sim", que podem ser entendidos como a conduta que pretende destruir e construir. A relação entre Apolo e Dioniso revela esse jogo. Apolo, o deus da bela forma e da individuaçáo, permite que Dioniso se manifeste. Dioniso, o deus da embriaguez e do dilaceramento, possibilita que Apolo se exprima. Um assegura ponderação e domínio de si; o outro envolve excesso e vertigem. Esse jogo, na minha compreensão, é o que Weber procura reconhecer entre o carisma e a burocracia.

Nesse sentido, o mundo não é só apolíneo-burocrático, é também dionisíaco-carismático. Se ainda não reconhecemos isso, talvez caiba à educação nos ajudar a fazer essa experiência, no mínimo como reflexão. Compreender que o mundo, como pleno vir a ser no sentido heraclitiano, não constitui um sistema, mas uma totalidade permanentemente geradora e destruidora de si mesma - um processo e não uma estrutura estável, um campo de forças instáveis em permanente tensão, não governado por leis - , ou seja, o mundo não se acha submetido a um poder transcendente e sua coesão não é garantida por substância alguma.

Mas assim também é a vida. $\mathrm{Na}$ análise que fez sobre o ascetismo protestante, Weber concluiu que as consequências não previstas advindas do ethos protestante são que não existe a garantia de outro mundo, sendo este o único com que se pode contar. Se quisermos a certeza de uma possível salvação, devemos nos voltar para este mundo.

Por seu lado, a filosofia de Nietzsche recusa que o suprassensível possa justificar o mundo; rejeita que um poder transcendente venha redimir a vida. $\mathrm{O}$ mundo subsiste; não é nada que vem a ser, nada que perece ou permanece. Não podemos atribuir-lhe nenhuma intencionalidade; não se deve conferir caráter teleológico algum. O que nos resta é a vida. Ela é o único critério que se impóe por si mesmo. Fazer qualquer apreciação, passar pelo crivo da vida, equivale a perguntar se contribui para favorecê-la ou obstruí-la. Portanto, é necessário nos perguntarmos se a educação moderna está favorecendo a vida ou não. 
Assim, a concepção dionisíaca/carismática nos traz a possibilidade de enfrentarmos o mundo e a vida tal como ela é. Transforma-se em martelo para derruir construtivamente as ideias e as condutas modernas. $\mathrm{O}$ espírito dionisíaco e o carismático surgem para assinalar que são possíveis "outros mundos”, tornando-se parâmetros também para avaliar a modernidade.

Se assim é, precisamos nos preparar para a existência do amor fati: nem conformismo, nem resignação, nem submissão passiva, mas amor. Nem lei, nem causa, nem fim, mas fatum. Assentir sem restriçóes a todo acontecer, admitir sem reservas tudo o que ocorre, anuir a cada instante tal como é, é aceitar amorosamente o que advém; "é dizer-sim ao mundo" (MARTON, 1994, p. 16).

Como leitor de Nietzsche, Weber parece recomendar também, como resposta a essa modernidade desumanizante, uma ética do amor fati. Se o destino do homem é enfrentar a vida racionalizada, isso exige uma virilidade bem calibrada para podermos aceitar, sem ilusóes políticas, religiosas, filosóficas, educacionais e morais, o caráter intramundano de nossas existências. Isso significa estarmos atentos a tudo o que há de mais terrível e doloroso, mas também de mais alegre e exuberante nessa existência. Aqueles que concebem a metafísica, isto é, que constroem mundos para além desse, que profetizam e esperam a superação do espetáculo da finitude, desprezando o que ocorre aqui e agora, supondo existir outra vida, se igualam ao "homem da ordem", o homem burocrático. Incluir a dimensão carismática e dionisíaca na educação, marcada por uma racionalização que despersonaliza, é afirmar, sem reserva, o fatum que espelha o mundo, que traduz a vida, que nos dá chance de formar a personalidade.

\section{Ensinar não é doutrinar: os limites do professor e a liberdade acadêmica}

Para Weber, quando motivaçôes, motivos políticos ou eclesiásticos influenciam e adentram o funcionamento de uma instituição de ensino, estamos diante apenas de uma parte do problema. Segundo ele, é um erro, também, quando professores transmitem opinióes favoráveis ou hostis ao Estado ou a qualquer setor da vida social. Não é tarefa das instituiçóes escolares inculcar valores morais e absolutos ou fundamentais nos estudantes. A elas cumpre garantir o exame dos 
[...] fatos, suas condições, leis e inter-relações; os conceitos, seus pressupostos lógicos e seu verdadeiro significado. Elas não ensinam e não podem ensinar o que deveria acontecer - uma vez que isso é matéria de valores e crenças fundamentais, de pontos de vista essenciais, que não podem ser "demonstrados" como uma proposição científica. (WEBER, 1989, p. 69-70).

O mesmo serve para o professor. Estaria indo além de suas fronteiras o professor que procurasse fornecer crenças e ideais a seus alunos, em detrimento do conhecimento e da compreensão dos fatos. Decidir sobre que valores ou quais deuses cultuar náo é da alçada da atividade docente, mas apenas propiciar as condiçóes para que o estudante possa escolher com responsabilidade, consciência e sentido qual a melhor atitude diante da vida. Os professores "[...] podem aguçar a capacidade do estudante para compreender as condiçóes reais de suas próprias açôes; podem transmitir-lhe a capacidade de pensar com clareza e 'de saber o que quer'" (WEBER, 1989, p. 69-70). Seja radical, moderado, de esquerda ou de direita, cumpre ao professor exercer o autocontrole, ajudando os estudantes a assumirem o hábito de agir com integridade intelectual.

A ideia que podemos depreender dessa posição é a de que, para Weber, o fundamental é o exercício da liberdade. O indivíduo deve conseguir por si mesmo as suas aspirações e metas, enfrentando as tarefas e os problemas da vida. Nesse caso, seria presunção do professor querer justificar e demonstrar cientificamente o sentido das convicçôes e juízos de valor de cada um e, além disso, pretender orientar ou decidir qual o melhor valor a ser seguido.

O dever de cada um é decidir se [suas] crenças últimas devem ser aceitas ou rejeitadas, se ele estará disposto a aceitar como condição os pré-requisitos e repercussões de concretização [dessas crenças], ou se considerará grandes demais os custos em proporção às chances de êxito. Não há professor que possa poupá-lo dessa decisão e nem ele poderá fazê-lo, pois esses não são problemas que se possam propor cientificamente [ou pedagogicamente]. (WEBER, 1989, p. 7I).

Na biografia que escreveu sobre o sociólogo alemão, Marianne Weber (1997), sua esposa, relata que Max Weber tinha convicção de que "[...] a felicidade humana não era o importante, mas, sim, que a liberdade e a dignidade humana eram [ou poderiam ser] os valores últimos e supremos, cuja 
realização deveria estar ao alcance de todos" (WEBER, 1997, p. 306, grifos do autor). Essa posição percorre toda sua vida. No caso de um homem de ciência, a sua conduta deve estar comprometida com a integridade de seu trabalho investigativo e, ao mesmo tempo, livre de qualquer controle externo. Nos textos sobre o significado da universidade, observamos a preocupação com o espaço que deve ser dado aos debates e às críticas, sem os quais não é possível o exercício sadio da atividade científica e pedagógica. Como defensor dos ideais liberais, Weber sentia que, em seu próprio país, a dominação burocrática difundia os seus tentáculos de maneira voraz por todos os lugares. A universidade alemã estava submetida às vontades frias dos integrantes do Estado ou da Igreja. A liberdade acadêmica corria sérios riscos. Em artigos publicados nos Jornais e Revistas alemães, considera que os membros do mundo universitário na Alemanha estavam perdendo o sentido da dignidade de seu papel acadêmico.

O sistema educacional alemão, subjugado ao domínio prussiano, estava estruturado com base nos desejos do governo. Friedrich Althoff (18391908), ministro da educação de 1881 a 1908, desejava acabar com a autonomia das universidades, interferindo em todos os assuntos, especialmente nas nomeaçóes de professores. O "sistema Althoff", como ficou conhecido, trouxe consigo o perigo de produzir uma nova geração acadêmica, não mais fiel às antigas tradiçóes da universidade alemá, influenciando de maneira contundente e arbitrária os seus rumos. Weber travou uma polêmica com os propósitos desse "sistema", pois, para ele, não são consideraçóes ligadas à amizade pessoal, mas sim, consideraçôes científicas, acadêmicas e educacionais sérias e realistas que devem nortear as nomeaçóes e promoçôes dentro das universidades. Segundo ele, “[...] o sistema vigente está tentando transformar os membros de nossa geração acadêmica em 'operadores' acadêmicos, em pessoas que se ajustarão a esse mecanismo sem qualquer reflexão mais profunda" (WEBER, 1989, p. 74). A universidade, dependente do Estado, coloca-se, portanto, na posição de "canto no tom de quem me dá o pão", incentivando a obediência política do estudante e do professor.

Em um artigo publicado no Frankfurter Zeitung (WEBER, 1989, p. 37-45), intitulado "O Caso Bernhard", Weber trata da nomeação do 
professor Ludwig Bernhard, feita pelo ministro prussiano sem qualquer consulta à respectiva congregação da Universidade de Berlim. Para ele, a iniciativa do ministro não passava de um escândalo. Contudo, o que mais o surpreendia era o fato de o professor ter aceitado a nomeação, tornando-se, assim, desrespeitoso com um dos elementos básicos de um professor - a "decência acadêmica". Aceitar as imposições políticas ou eclesiásticas corresponde à perda da "confiança intelectual" dos colegas. Parecendo angustiado com essas atitudes sem caráter, Weber arremata: "[...] foi-se o tempo em que [a nomeação para um cargo de professor] era encarada como grande distinção científica e acadêmica”.

Segundo Weber, a independência acadêmica e o mérito intelectual não podem ser aniquilados por preferências e interesses pessoais, políticos ou eclesiásticos. Como afirma ele, “[...] eventos como o 'caso Bernhard', e as situações de que esse 'caso' é sintoma, estão fadados a diminuir seriamente o respeito que o corpo discente mantém pelos professores da universidade” (WEBER, 1989, p. 45).

Em outro artigo (WEBER, 1989, p. 57-63), ele trata dos obstáculos que os interesses eclesiásticos causam à liberdade acadêmica. Cita o caso do professor e amigo Robert Michels que, pretendendo habilitar-se em uma universidade, foi impedido porque manifestava publicamente convicções sociais e democráticas, mas, sobretudo, porque "não [teria permitido] que seus filhos fossem batizados”. E conclui: “[...] enquanto tais opinióes prevalecerem, será impossível agir como se possuíssemos uma 'liberdade acadêmica." 5 Segundo ele, seria merecedor de desprezo quando os sacramentos são usados para tal fim. Portanto, náo é possível falar em liberdade acadêmica, quando fatores dessa natureza adentram o campo intelectual. O momento histórico da Alemanha permite "liberdade" na atividade científica apenas dentro dos limites da "aceitabilidade política e eclesiástica". Nesse sentido, Marianne Weber (1997, p. 354). menciona que

5 É preciso compreender que quando Weber utiliza aspas em alguns conceitos, como é o caso de "liberdade acadêmica", aqui ele o faz apenas para ilustrar que não está adotando nem concordando com a definição corrente, mas querendo mostrar que as ações humanas e sociais são apenas arremedos do significado profundo do conceito usado. 
[...] um dos princípios de [Max] Weber era que todas as disciplinas baseadas em "valores", particularmente nos campos da filosofia, da história e da ciência política, representantes de diversas convicções deviam trabalhar, se possível, uma do lado da outra. Uma universidade como ele a imaginava não devia ser uma "igreja" nem uma "seita" nem uma instituição defensora do estado, mas um foro de liberdade e de luta intelectual.

A "liberdade acadêmica", como Weber a diagnosticava na Alemanha de sua época, estava muito distante daquela defendida por ele. Muitos colegas de cátedra tinham um comportamento hostil em relação à liberdade na atividade docente, defendendo que a tarefa das universidades era formar jovens para servir ao Estado e à Igreja. Estes professores consideravam que não se podia confiar, por exemplo, nos socialistas, uma vez que, segundo eles, eram inimigos da ordem social e política alemã e que estavam decididos a destruí-la. Portanto, nessa visão, um professor deveria ser admitido na ordem pública, não somente por suas qualificações científicas, mas, sobretudo, pela "sua docilidade perante as autoridades políticas e seus costumes eclesiásticos”. Qualquer "protesto público contra o sistema político reinante [justificava] a perda de uma cátedra”. Dessa maneira, restaria às pessoas, que foram nomeadas professores universitários, a sala de aula como lugar onde poderiam expressar-se como queriam, independentemente de toda autoridade; porém, desde que não tornassem públicas suas críticas.

"A liberdade de ciência, de estudo e de ensino" em uma universidade certamente não existe quando se faz com que a nomeação para uma função docente seja dependente do fato de que se possua - ou que se simule - um certo ponto de vista que seja "aceitável nos círculos mais altos" da Igreja e do Estado. (WEBER, 1989, p. 64).

A crítica de Weber à falsa liberdade acadêmica do final do século XIX, na Alemanha, deve ser entendida, desse modo, como um sinal de sua posição sobre o significado que o cientista ou o professor tem na modernidade. Pelo menos é o que quero evidenciar a seguir.

Para Weber, a falta de dignidade intelectual e docente está em nos reduzirmos a ideias cristalizadas, isto é, à busca de uma institucionalização do conhecimento, como se fosse possível transformar os valores, as perspectivas em que cada um acredita, em fundamento último da existência humana. Ao nos comportarmos assim, estamos sufocando a criatividade e 
os voos imaginativos, qualidades pertencentes àqueles que têm propriedades carismático-dionisíacas ${ }^{6}$, qualidades muitas vezes ausentes no ambiente intelectual. Observando a realidade alemá, Weber constata o quanto os professores estão sujeitos a um processo de burocratização e apolinização da vida.

Dessa posição weberiana, é possível extrair alguns apontamentos para a prática e a postura do professor na sala de aula, para além de uma boa didática que leve e eleve os estudantes a agirem em direção à dignidade intelectual, elemento fundamental para uma compreensão significativa da vida social.

$\mathrm{O}$ professor, se quiser permanecer nos limites da honestidade intelectual, deve ter a consciência de que não é possível ter o domínio das rodas da história, fazendo-as girar de acordo com o seus desejos e, ademais, indicar que essa ou aquela é a melhor. A ele cabe apenas garantir e respeitar a autonomia decisória dos estudantes e, não sendo arrogante, não educá-los dentro de crenças e pontos de vista que considera essenciais e, a partir daí, querer doutrinar. Portanto, Weber faz um diagnóstico contundente do significado que o professor e o cientista, sobretudo aqueles que tratam das açóes humanas, adquirem na modernidade. A eles cumpre identificar os seus limites e ter consciência deles. Nenhuma ação pedagógica ou científica teria condiçôes de instaurar um "consenso cultural".

Alguém que deseje esse consenso - seja professor, cientista, Estado ou Igreja - deve pôr de lado todo tipo de instrução em valores e crenças últimos; [...] [enfim], ter o mais rígido dever de procurar não manifestar a própria posição na luta entre os ideais. (WEBER, 1989, p. 73).

A sala de aula, a pesquisa e os espaços escolares e universitários devem ser fóruns onde se busca fortalecer a compreensão dos pontos de vista últimos de cada um e não uma arena para a divulgação de ideais de grupos, "igrejas" ou "seitas".

6 Isso significa que o mundo é considerado como pleno devir, não se constituindo um sistema, mas uma totalidade permanentemente geradora e destruidora de si mesma - um processo e não uma estrutura estável, mas um campo de forças instáveis em permanente tensão, não governado por leis; não se acha submetido a um poder transcendente e sua coesão não é garantida por substância alguma, como propunha o caráter burocrático-apolíneo. 
Enfim, Weber não acredita em programas e projetos que buscam o consenso da vida cultural. O que significa que a sociedade cosmopolita e o desenvolvimento pleno dos germes de humanidade que há em nós, como esperado pela filosofia kantiana, não são mais possíveis no mundo moderno desencantado. Aqueles que "inventam" profecias e querem doutrinar a partir delas podem provocar os resultados mais desastrosos. Em $A$ Ciência como Vocação, ele faz a seguinte afirmação: "[...] as profecias que caem das cátedras universitárias não têm outro resultado senão o de dar lugar a seitas de fanáticos e jamais produzem comunidades [científicas e pedagógicas] verdadeiras” (WEBER, 1995, p. 453). Ao homem moderno é apenas possível "suportar virilmente esse destino de nossa época”. Quem não for capaz disso deve voltar, "[...] com simplicidade e recolhimento, aos braços abertos e cheios de misericórdia das velhas Igrejas"; esta atitude, diz Weber, "[...] é superior ao procedimento de todas as profecias de catedráticos que não compreendem claramente que nas salas de aula [...] nenhuma outra virtude é válida a não ser a simples integridade intelectual” (WEBER, 1995, p. 453).

Para os intelectuais e professores modernos, que tratam de criar substitutos de religióes, profetas, discípulos e igrejas, que fabricam experiências e edificam sobre elas carreiras literárias, Weber não sentia mais que desprezo. Dizia que era simplesmente um tipo de autoengano. Nenhum intento de criar artificialmente arte monumental ou religiôes novas ou novas comunidades poderia ter êxito em uma era, cuja vida pública esteja táo desprovida de profecia, de pneuma e de carisma. Quanto tempo iria durar esse tempo? "Vem a manhã, mas ainda é noite. Se quereis perguntar, voltai noutro dia”. Diante desse destino quase sem sentido, Weber pedia aos estudantes simplesmente que cumprissem com "[...] 'as exigências de cada dia' - tanto no campo das relaçóes humanas, como das atividades profissionais. Esta exigência, decerto, é simples e clara, se cada um de nós encontra e obedece ao 'demônio' (daimon) que tece as teias de [nossas] vidas” (WEBER, 1995, p. 453).

Em um tempo que se caracteriza pela racionalização e pelo desencantamento do mundo, ao homem cumpre apenas ouvir a sua voz interior, a sua consciência, pois náo há mais valores supremos e sublimes que 
orientam a sua conduta. Viveríamos em uma época de luta irreconciliável de todos os valores, não havendo mais uma única perspectiva que unificasse as açóes humanas. Diante desse quadro, que Weber chama de politeísmo de valores, o professor náo é e não pode ser um mistagogo ${ }^{7}$, ou seja, o portador de uma mensagem salvadora ou profética, orientando as açóes de todos os homens. É dessa posição weberiana que podemos extrair elementos mais ricos e mais aprofundados para se pensar a educação.

\section{Considerações finais}

A partir do diagnóstico weberiano, se é possível construir uma ação educativa na modernidade, ela deve estar fundada em um questionamento permanente de suas próprias condiçóes. No final do texto $A$ ética protestante e o espirito do capitalismo, ele afirma a necessidade do surgimento de novos pensamentos e de novos ideais para contraporem-se a um mundo que transformou o homem em um ser insensível e calculista. Aponta para a possibilidade de rompermos com o estado de coisas, originado no capitalismo moderno.

Portanto, é preciso pensar em uma terapia das condiçóes modernas. Essa terapia deve ser de tal maneira que desconfie da razáo que se coloca como um princípio ordenador da relação homem-mundo, expressa no caráter burocrático da existência. O burocrata ou o "espírito de peso", como diz Nietzsche, julga que existem leis universais, acredita que há regras de conduta válidas para todos e, estabelecendo coerção, norma, zela pelos valores instituídos e estatuídos.

Retomar o espírito carismático e o dionisíaco pode ser o "caminho" para aqueles que querem a liberdade. A educação e nossas práticas pedagógicas podem nos ajudar nesse processo. Ao invés de uma vida fundada na rigidez, na frieza e no cálculo, experimentar a sensação fornecida pelo movimento que resulta da dança. Ver a vida como dança, como um jogo, é pôr em cena variados pontos de vista, diferentes perspectivas, fazendo surgir aspectos inesperados da existência. Com a dança, evoca-se o fluxo vital; com ela, alude-se à permanente mudança de tudo o que existe, contra

7 Pessoa que inicia outros em crenças místicas; um educador ou pessoa que tem conhecimento dos "mistérios sagrados" e que ensina as doutrinas. 
qualquer dogmatismo. Pondo sob suspeita toda e qualquer certeza, antecipa ideias para fazer experimentos com o pensar. Cadenciada, a dança póe em xeque a aparente imobilidade das coisas, a rigidez imposta ao pensamento e à vida. A dança é ainda alegria, alegria dionisíaca. Assim, podemos pensar em uma educação que leve em conta a dança alegre dionisíaca e o espírito extático do carisma.

Como na ação carismática, é preciso orientar a vida a partir da desconfiança, evitando somente as convicçóes; abandonar comodidades, renunciando à segurança. É preciso ousadia para abrir mão de antigas concepçôes, libertar-se de esperanças vãs e fazer brotar "espíritos livres”. Assim diz Nietzsche:

[...] onde um homem chega à convicção fundamental de que é preciso que mandem nele, ele se torna "crente"; inversamente, seria pensável um prazer e força a autodeterminação, uma liberdade da vontade, em que um espírito se despede de toda crença, de todo desejo e possibilidades, e mesmo diante de abismos dançar ainda. Um tal espírito seria o espírito liure par excellence. (NIETZSCHE, 1978, p. 215, grifo do autor).

É necessário uma educação que faça o clinamen surgir e ressurgir, que introduza no mecanismo determinista o espaço de libertaçáo, que consiste em romper o determinismo inerente a qualquer situação objetiva e, de forma desviante, abrir espaço para o exercício da autonomia.

Ser mortal, o homem constrói sua liberdade no tempo, no tempo desta vida que deve ser transformado em tempo de felicidade. Para isso, Weber vai considerar necessário que enfrentemos o mundo burocrático, que estabelece um cenário racional, para que o mundo e a vida não deixem de ser apenas uma "possibilidade abstrata". Essa deve ser a responsabilidade da ação educativa. Uma educaçáo que, ao invés de burocratizar e normatizar friamente, liberte, rompa e revolucione, expanda-se, autocontroladamente, garantindo a autonomia. A burocracia, que tende a representar a ausência de liberdade, pode ser impedida de avançar ainda mais se a colocarmos em um confronto equilibrado com as qualidades carismáticas, e o professor pode cumprir um papel importante nesse processo.

Concluindo, podemos afirmar que a sociologia weberiana nos permite adotar uma postura analítica mais apurada sobre a sociedade, a ciência e 
a educação. Ela traz questóes pertinentes sobre as açóes humanas na atualidade. Vemos em Weber não apenas um autor que constata a tragédia do mundo moderno, no qual convivem os paradoxos de uma existência fundada no cálculo, na frieza e na racionalidade, o que pode nos dar a falsa ideia de que ele é pessimista e profundamente desiludido com a vida, a sociedade e os humanos, mas também alguém que lida com as possibilidades, isto é, com a chance de realização de algumas perspectivas. Nem tudo ainda está perdido: nem a liberdade, nem o sentido da vida. É possível um projeto que equilibre, ou pelo menos leve em conta, as tensôes e os conflitos que compóem e formam a nossa existência de maneira inovadora sem exageros e de certa maneira esperançosa.

\section{Referências}

DOW JR., Thomas E. An analysis of Weber's work on charisma. British Journal of Sociology, v. 29, n. I, p. 83-93, march 1978.

FOUCAULT, Michel. O que é o lluminismo. In: ESCOBAR, Carlos Henrique (org.). Michel Foucault (1 926-1 984): o Dossier - últimas entrevistas. Rio de Janeiro: Livraria Taurus Editora, 1984. p. 112.

HENRICH, Dieter; OFFE, Claus; SCHLUCHTER, Wolfgang. Max. Max Weber e o projeto da modernidade. Lua Nova, São Paulo, v. 22, p. 229-257, 1990.

MARTON, Scarlett. Por uma filosofia dionisíaca. Kriterion, Belo Horizonte, v. 35, n. 89, p. 9-20, jul. 1994.

NIETZSCHE, Friedrich. Obras incompletas. São Paulo: Abril Cultural, 1978. (Os Pensadores).

PESSANHA, José Américo Motta. As delícias do jardim. In: NOVAES, Adauto (org.). Ética. São Paulo: Companhia das Letras, 1997. p. 57-85.

SOUZA, Jessé. Patologias da modernidade: um diálogo entre Habermas e Weber. São Paulo: Annablume, 1997.

WEBER, Marianne. Biografía de Max Weber. México: Fondo de Cultura Economica, 1997.

WEBER, Max. A ética protestante e o espírito do capitalismo. São Paulo: Pioneira, 1967.

WEBER, Max. Ensaios de Sociologia. Rio de Janeiro: Guanabara Koogan, 1982.

WEBER, Max. Sobre a universidade: o poder do Estado e a dignidade acadêmica. São Paulo: Cortez, 1989.

WEBER, Max. Metodologia das Ciências Sociais. São Paulo: Cortez, 1995. Parte 2. 


\section{The sociology of education of Max Weber: the clinamen in pedagogical practice}

\section{Abstract}

This article consists, essentially, of an analysis of Max Weber's thinking, in order to seek a possible contribution in the field of education on present. When expose his comprehension about the rationalization process, having on bureaucracy as one of its most striking manifestations, Weber understands human actions as constituted by a permanent tension. There would not be a meaning in the world, with universal validity, that could guide existence. In this aspect, education needs to acquire another meaning, that is, an education that does the clinamen emerge and revive, introducing on determinist mechanism the space of liberation, which consists in breaking the inherent determinism in any objective situation and, in a deviant way, to promove aperture for the exercise of autonomy. If to the teacher belongs the obligation to provide some hope for the life of his students, it must be established from the recognition of the agonistic character of existence. To do in this way, is guarantee integrity and intellectual freedom.

Keywords: Disenchantment of the world. Bureaucracy. Rationalization process. Sociology of education. Pedagogical practice. 